\title{
Mesenchymal Progenitor Cells: Tissue Origin, Isolation and Culture
}

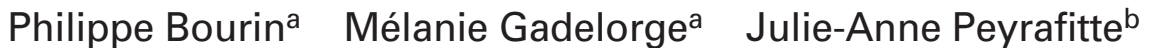 \\ Marilyn Gomez ${ }^{a} \quad$ Christine Rage $^{a} \quad$ Luc Sensebéc $^{2}$ \\ a Laboratoire d'Ingénierie cellulaire, GECSoM, Etablissement Français du Sang Pyrénées-Méditerranée, \\ bUMR CNRS UPS 5241, Toulouse, \\ ${ }^{\mathrm{c}}$ Laboratoire de recherche, GECSoM, Etablissement Français du Sang Centre-Atlantique, Tours, France
}

Sandrine Fleury-Cappellesso ${ }^{\mathrm{a}}$

\section{Key Words}

Multipotent mesenchymal stromal cells - Tissue origin . Cell culture

\section{Summary}

Since the pioneering work of Alexander Friedenstein on multipotent mesenchymal stromal cells (MSCs), a tremendous amount of work has been done to isolate, characterize and culture such cells. Assay of colony forming unit-fibroblasts (CFU-Fs), the hallmark of MSCs, is used to estimate their frequency in tissue. MSCs are adherent cells, so they are easy to isolate, and they show contact inhibition. Thus, several parameters must be taken into account for culture: cell density, number of passages, culture medium, and growth factors used. The purity of the initial material is not a limiting parameter. Similar but not identical cell populations are found in almost all mammal or human tissues. MSCs seem to be very abundant in adipose tissue but at low frequency in blood from umbilical cord or in adult tissue. The culture conditions are very similar, whatever the source of cells. Because of their favorable properties, MSCs are very promising tools for regenerative medicine.

\section{Introduction}

In the 1960s, Alexander Friedenstein, a Soviet researcher, discovered multipotent progenitors of conjunctive tissue in bone

\section{Schlüsselwörter}

Multipotente mesenchymale Stammzellen .

Gewebeursprung · Zellkultur

\section{Zusammenfassung}

Seit der bahnbrechenden Arbeit von Alexander Friedenstein zu multipotenten mesenchymalen Stammzellen (MSCs) wurde enorm viel Zeit und Arbeit in die Isolierung, Charakterisierung und Kultivierung dieser Zellen investiert. Zur Bestimmung ihrer Häufigkeit in Gewebe wird der CFU-Fs (colony forming unit-fibroblasts)-Assay, das Markenzeichen von MSCs, verwendet. Da MSCs adhärente Zellen sind, sind sie leicht zu isolieren. Sie weisen eine Kontaktinhibition auf. Daher müssen verschiedene Parameter wie Zelldichte, Anzahl der Passagen, Kultivierungsmedium und Wachstumsfaktoren bei deren Kultivierung berücksichtigt werden. Die Reinheit des Ausgangsmaterials ist kein limitierender Faktor. Ähnliche, aber keine identischen Zellpopulationen lassen sich in beinahe allen Säugetier- bzw. menschlichen Geweben finden. MSCs scheinen sehr zahlreich in Fettgewebe, aber nur in geringer Frequenz in Nabelschnurblut und in ausgewachsenem Gewebe vorzukommen. Die Kultivierungsbedingungen sind sehr ähnlich, egal woher die Zellen stammen. Wegen ihrer günstigen Eigenschaften sind MSCs ein sehr vielversprechendes Instrument in der regenerativen Medizin.

marrow. Cultivation of the bone marrow cells of rabbits or rodents at low density in a liquid medium containing serum revealed colonies of long, plastic-adherent cells with fibroblastic appearance [1]. These colonies came from only one cell type,

\begin{tabular}{ll}
\hline KARGER & $\odot$ 2008 S. Karger GmbH, Freiburg \\
Fax +4976145207 14 & Accessible online at: \\
$\begin{array}{l}\text { E-mail Information@Karger.de } \\
\text { www.karger.com }\end{array}$ & www.karger.com/tmh
\end{tabular}

Dr. Philippe Bourin

Laboratoire d'Ingénierie cellulaire

Etablissement Français du Sang Pyrénées-Méditerranée

75 rue de Lisieux, 31300 Toulouse, France

Tel. +33 534 5024-78, Fax -70

E-mail philippe.bourin@efs.sante.fr 
named colony-forming unit-fibroblasts (CFU-Fs). The cells were quiescent at the beginning of culture, but cultured adherent cells, sown under the renal capsule of syngeneic animals, generated fibrous tissue, bone or osseous trabecula containing hematopoietic marrow (in a proportion of approximately 1:3 for each). Study of chimeric animals showed that the fibrous tissue and bone came from the donor and the hematopoietic tissue from the receiver [1].

Mesenchymal progenitors are found in the bone marrow of many mammal species. However, their frequency and potential for cultivation differs among species. Thus, in rodents, mesenchymal progenitors of rat are easy to cultivate but not those of mouse. Only those of the Balb/C and $\mathrm{FVB} / \mathrm{N}$ strains really proliferate [2]. The growth of CFU-Fs from other mouse strains is inhibited by contaminating macrophages, which are very difficult to eliminate without depleting cell numbers [3]. The presence of CFU-Fs in humans was described in 1980 [4].

Arnold Caplan, at the beginning of the 1990s, named CFU-Fs mesenchymal stem cells (MSC) and showed that they generate not only bone and medullar stroma but also cartilage, tendons, and muscle [5]. The cells are also known as marrow stromal cells, and in 2005, the International Society for Cellular Therapy clarified the acronym MSC as multipotent mesenchymal stromal cell [6], because evidence is lacking that these cells have all properties of stem cells, as defined by Potten and Loeffler [7].

\section{Mesenchymal Cell Sources}

Since the first description of CFU-Fs, the most studied source of mesenchymal cells is bone marrow. MSCs are present in the mononuclear fraction of medullar cells. The quantification of CFU-Fs allows for estimating the number of MSCs in bone marrow to be between 1 per $10^{4}$ and 1 per $10^{5}$ mononuclear cells. A significant factor affecting this frequency is the age of the donor. The number of CFU-Fs is higher in children than in adults: 29 per $10^{6}$ as compared with 3.2 per $10^{6}$ mononuclear cells [8]. This frequency also depends on the technique of aspiration; the concentration of CFU-Fs per milliliter decreases with increased volume of aspirated marrow for each puncture because of blood dilution [9]. Bone marrow is commonly aspirated from the sternum or iliac crest. It can also be obtained from vertebrae [10]. The concentration of CFU-Fs is $70 \%$ higher for this last site. Some pathological conditions or treatments have an effect on the number of MSCs in bone marrow. Indeed, the frequency of CFU-Fs is abnormal in patients with aseptic osteonecrosis of the femoral head related to corticosteroid therapy [11]; no MSCs are found in the heart of the necroses, and their frequency is decreased in the femoral head and iliac bone although their potential for differentiation does not seem to be compromised [12].

MSCs can also be obtained directly from trabecular bone. Thus, the osseous fragments obtained at the time of total prosthesis of the hip are a source of MSCs. The number of CFU-Fs present in mononuclear cells recovered from these fragments is of the same order as that obtained from medullar aspirations $\left(1 \mathrm{CFU}-\mathrm{F}\right.$ for $3.2 \approx 10^{4}$ cells vs. $1-10 \mathrm{CFU}-\mathrm{Fs}$ for $1 \times 10^{5}$ cells) [13]. The MSCs obtained in this material have identical potential for differentiation compared to MSCs from bone marrow, but proliferation quickly decreases after the first phase of culture (L. Sensebé, unpublished data), which could be due to the age of donors.

Although bone marrow is the initial material of choice for culture of mesenchymal progenitor cells, related cell populations with similar properties are found in almost all tissues in mammals or humans $[14,15]$. Thus, certain tissues such as fat tissue, fetal tissue and liquids (amniotic liquid, placenta, umbilical cord blood (CB), and Wharton's jelly) become alternative sources of mesenchymal progenitor cells. Harvesting such tissue is much less harmful than harvesting bone marrow. Other sources are more difficult to access, e.g. lung and synovial tissue, or rarely considered, e.g. peripheral blood.

Fat tissue is an important source of cells linked to MSCs. These cells are commonly called adipose-derived stromal cells (ADSCs) or ASCs (used here, according to the International Federation of Adipose Therapeutics and Science). Fat tissue contains at least 100 times more ASCs than bone marrow contains MSCs. These cells also have a greater potential for proliferation [16]. Thus, we estimated that less than $1 \mathrm{~g}$ of fat tissue could allow for generating $10^{8}$ ASCs in approximately 14 days of culture. The differentiation and immunomodulatory potential of these cells is equivalent to that of MSCs [17-20]. In vitro and in vivo, ASCs show potential for differentiation in cardiac tissue and endothelial cells, which reinforces interest in their use $[21,22]$. However, their phenotype is slightly different from that of MSCs since, contrary to MSCs, they express CD34 antigen [23]. This marker disappears during culture, which can explain why it is sometimes not detected. In the case of fat tissue, the sites currently harvested are subcutaneous, in the abdominal zone. The tissue is obtained by liposuction or biopsy. Work in the mouse seems to indicate qualitative differences depending on the sites of harvest.

The possibility of obtaining adherent stroma from the $\mathrm{CB}$ was reported for the first time in 1994 [24], but other laboratories could not reproduce the described technique. In 2000, Mingell and colleagues [25] obtained MSCs from CB in approximately $25 \%$ of harvests. These findings were later confirmed [26, 27]. However, MSCs cannot be isolated from all CB (60\% at the maximum). The critical parameters for success are the time between harvest and the beginning of culture ( $15 \mathrm{~h}$ seems to be the maximum), the volume of $\mathrm{CB}(>33 \mathrm{ml})$, and the total quantity of mononuclear cells (higher than $10^{8}$ ) [28]. After cryopreservation, the chances of success are even more reduced (0-19\% [29]). Although MSCs have lower concentration in $\mathrm{CB}$ than in marrow ( 1 per $10^{8}$ cells vs. 1 per $10^{5}$ cells), they have a greater potential for proliferation $[27,28]$. The potential for differentiation of CB MSCs in different tissues is also broad. After enrichment by depletion, CB MSCs have 
been found to differentiate not only in the mesodermal but also in the endodermal and ectodermal pathway [27, 30, 77]. The existence of accredited networks of CB banks and the possibility of great potential for differentiation could increase the use of CB to produce MSCs for clinical use, provided that the cells are isolated before cryopreservation.

Mesenchymal progenitor cells present in tissues or fetal fluids such as amniotic liquid, placenta or Wharton's jelly in general have greater proliferation and differentiation potential than bone marrow MSCs [31-33]. They also seem to express certain markers of stem cells, such as Oct-4, more strongly [32]. Like ASCs, placental MSCs are able to easily differentiate in endothelial cells.

The presence of CFU-Fs in blood of adult mammals was shown at the beginning of the 20th century [34]. Contamination by fragments of conjunctive tissue, which explained this presence, was invalidated by experiments. However, the existence of circulating MSCs remains a discussed subject [35, 36]. Regardless, MSCs are in very restricted number in the blood and, moreover, are not found in all tested individuals. In humans, mobilization of granulocyte colony-stimulating factor (G-CSF) or granulocyte-macrophage colony-stimulating factor (GM-CSF) could increase their frequency, although not all studies has confirmed this possibility [35]. Charbord and associates [37] found MSCs mobilized by hypoxia in rat. Whether such pathological conditions can produce the same effect in humans is of interest. These circulating MSCs seem to have the same spectrum of differentiation as bone marrow MSCs.

An interesting study on humans showed osteoblastic circulating progenitors identifiable by their surface expression of osteocalcin [38]. These cells exist at much higher frequency than circulating MSCs described in other publications (1-5\%). Moreover, this frequency is increased with significant osseous formation (with adolescence or fracture). Sorted cells are able to form bone in vivo. On culture, they seem to adhere only gradually, so non-adherent cells must be kept in culture during a long period. The exact filiations of these cells compared to MSCs cannot be determined because the authors did not test other types of differentiation. Finally, even if peripheral blood is easy to access, it does not seem to constitute a source of MSCs suitable for therapeutic use. However, the presence of MSCs in peripheral blood of normal humans raises the question of the reason for their presence and the mechanisms.

MSCs are also found in dental pulp or periondontal ligaments and synovia [39-41]. Because of their mesenchymal origin and differentiation potential, satellite cells in muscle must be considered mesenchymal progenitor cells as well [42].

The very broad distribution of mesenchymal progenitor cells and findings from recent studies suggest that such cells are located in the perivascular zone [43]. This could be explained by extensive migration with the formation of the vascular network during the life of the fetus. Mesenchymal progenitor cells may be in a specific niche, the cellular and molecular composition of which remain to be determined.

\section{Mesenchymal Cell Isolation}

The purification of mesenchymal cells by use of membrane markers is described elsewhere in this special issue [78]. For cells isolated from bone marrow and other fluids, the initiation of culture can start directly or after a simple centrifugation. For cells found in tissue, the isolation starts with enzymatic dissociation that releases the cells from the extracellular matrix. The commonly used enzyme is collagenase. After digestion, the cellular suspension is filtered to eliminate the non-dissociated pieces of tissue and cellular aggregates. For fat tissue, an additional step of centrifugation eliminates the mature adipocytes, which float. In general, the mesenchymal progenitor cells are then purified because of their property of adherence to the plastic. After initiation of culture, the cells are left to adhere for $24 \mathrm{~h}$ to 7 days. Then non-adherent cells are eliminated with a change of medium. This method is reliable and inexpensive. However, other cells such as macrophages and endothelial cells also adhere, necessitating a certain period of culture and/or successive passages for elimination [2]. The MSCs have a density of 1.073 which allows for enriching the cellular suspension by layering it on a density gradient [44]. Medullar MSCs contain a subpopulation of small-sized cells $(<7 \mu \mathrm{m})$ with fast renewal (so-called RS cells) and great potential for differentiation $[45,46]$. RS cells are sorted after culture by use of a $10-\mu \mathrm{m}$ filter. They have a cloning efficiency of approximately $90 \%$ but evolve in larger cells quickly if the cellular density increases [47]. These techniques are simple to perform and lead to a homogeneous population of cells with a fibroblastic type.

\section{Mesenchymal Cell Culture}

Here we describe mainly culture of bone marrow MSCs. We will indicate the specific conditions for cells of other origins when they differ. At the start of culture, MSCs appear as round and refringent cells. After a few days, the cells acquire a fibroblastic aspect (fig. 1a and c). MSCs are adherent cells with contact inhibition; several parameters are significant: oxygen tension, culture density, number of passages, culture medium, and the growth factors used. The purity of the initial material is not a limiting parameter because total marrow can be sown without separation of mononuclear cells, which is also found with cells from adipose tissue.

\section{Oxygen Tension}

Cell culture at $20 \%$ of oxygen does not correspond to physiological conditions. In fact, oxygen tension is much lower in vivo and differs depending on the tissue and even the position in a given tissue. For example, in bone, oxygen tension may vary from 12.5 to $1 \%$. Thus, MSCs are exposed to hypoxia in vivo. MSC culture under hypoxia enhances their proliferation and extends their lifespan [48, 49]. Hypoxia also increases extracellular matrix synthesis and organization, and modifies the
162

Transfus Med Hemother 2008;35:160-167
Bourin/Gadelorge/Peyrafitte/ Fleury-Cappellesso/Gomez/Rage/Sensebé 
Fig. 1. Mesenchymal cells in culture.

The cells from a bone marrow or $\mathbf{b}$ fat tissue cultivated in $\alpha$-modified Eagle's medium $(\alpha \mathrm{MEM})+$ $10 \%$ fetal calf serum (FCS) + antibiotic with change of medium every 3 or 4 days show similar aspects. Subculture at low density reveals small, round and refringent cells, which correspond to cells during division (white arrow) for $\mathbf{c}$ MSCs as well as for d ASCs. Magnification 40x (a and b) or 100x (c and d)
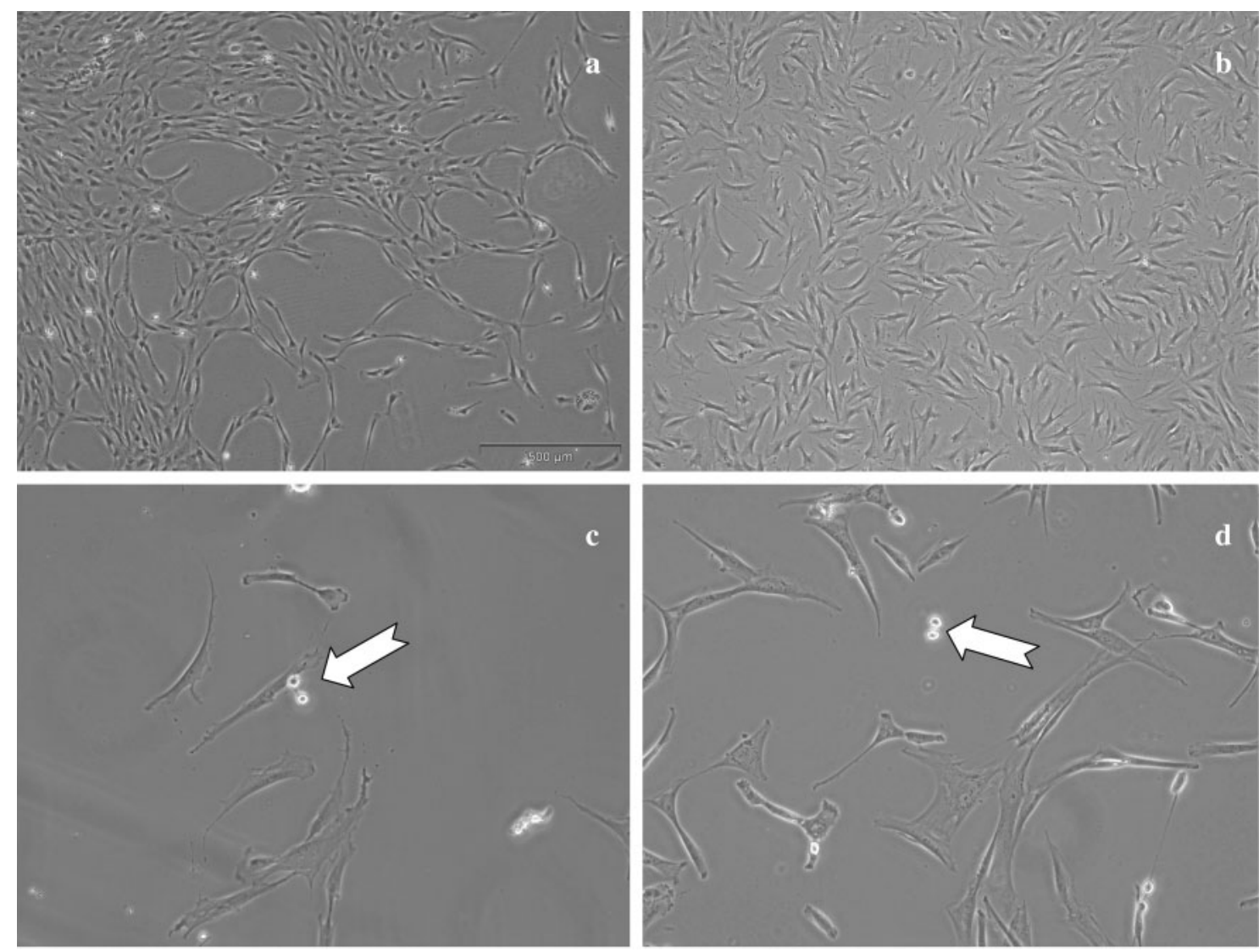

expression of genes, mainly those involved in glycolysis and metabolism [50]. It also induces up-regulation of growth factors such as vascular endothelial growth factor (VEGF), heparin-binding endothelial growth factor (HB-EGF) or placenta growth factor. However, under hypoxia, the differentiation potential of MSCs seems to be reduced [48, 51].

\section{Cell Culture Density}

The seeding density is a critical parameter to ensure the optimal growth rate of MSCs as well as to maintain the differentiation potential. For initial culture (primo-culture), many protocols involved cell densities up to $200 \times 10^{3}$ cells $/ \mathrm{cm}^{2}$ [52] . Substantially lower densities are possible. A cell density of $50 \times 10^{3}$ cells $/ \mathrm{cm}^{2}$ has achieved a good rate of proliferation in primo-culture [53]; for the next passages, a cell density between 5 and $7 \times 10^{3}$ cells $/ \mathrm{cm}^{2}$ was used $[52,54]$. However, the most immature progenitors were achieved with very low culture density (from 1 to 50 cells $/ \mathrm{cm}^{2}[45,55]$ ). Increasing the cell density from 10 to 1,000 cells $/ \mathrm{cm}^{2}$ led to reduced expansion (from 500 to 30 times) with reduced cloning efficiency which fell from 36 to $12 \%$ CFU-Fs. These results could explain why in certain experiments, with cell densities of $6 \times 10^{3}$ cells $/ \mathrm{cm}^{2}$, the proliferation rate is quickly reduced and differentiation potential lost. When the surface and duration of the culture are kept constant, culture at 1,000 cells $/ \mathrm{cm}^{2}$ gives 5 times more cells than that at 50 cells $/ \mathrm{cm}^{2}$ [55]. At low cell-culture density, the consumption of medium and the culture sur- face required to obtain a reasonable amount of cells considerably increases the cost of experiments. Thus, for passaging, a cell density of $10^{3}$ cells per $\mathrm{cm}^{2}$ represents an acceptable compromise, with a correct maintenance of MSC potentials and sufficient number of cells produced for study [53]. For ASCs, the cell densities for the primo-culture and for the following passages are lower [21]. We found it possible to sow ASCs at $4 \times 10^{3}$ cells $/ \mathrm{cm}^{2}$ in primo-culture and $2 \times 10^{3}$ cells $/ \mathrm{cm}^{2}$ for the next passages. For $\mathrm{CB}$ or peripheral blood, however, the cell densities of primo-culture are much higher $\left(10^{6}\right.$ cells $\left./ \mathrm{cm}^{2}\right)$ than that for the other tissues.

\section{Number of Passages}

Since MSCs are adherent and show contact inhibition, MSC culture, when confluence is reached, requires cell 'passage', whereby MSCs are detached from their culture support, generally by the action of a proteolytic enzyme (trypsin), and then sown on a new support at less density (see above paragraph). After one or more passages, one can obtain a great quantity of MSCs. Moreover, the culture conditions and the successive passages are enough to ensure the final purity of MSCs and the disappearance of other initially adherent cells (macrophages, lymphocytes, endothelial cells). However, these successive passages can alter the characteristics of MSCs. In rat, bone marrow MSCs retain their proliferative characteristics and differentiation potential until the 15th passage, but in humans the proliferation rate is reduced and the multipotentiali- 

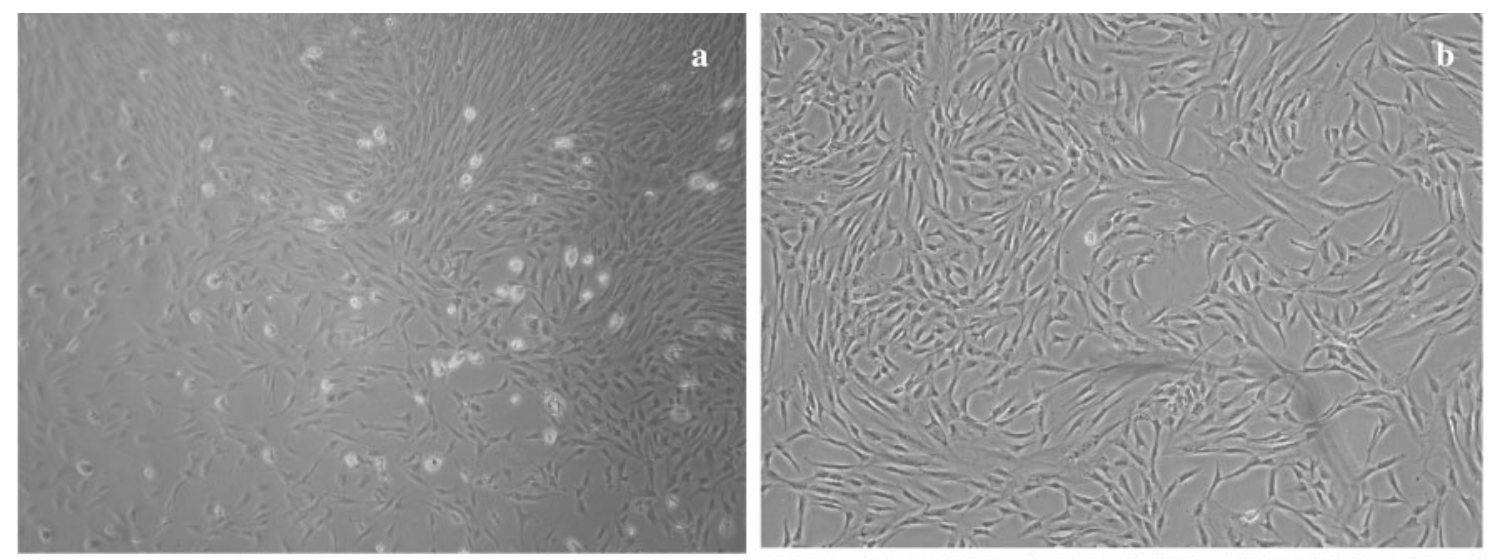

Fig. 2. Morphology of MSCs or ASCs cultured with FCS or platelet lysate (PL). $\operatorname{MSCs}(\mathbf{a}, \mathbf{b})$ or ASCs (c, d) were cultivated in $\alpha \mathrm{MEM}+10 \%$ FCS + antibiotic $(\mathbf{a}, \mathbf{c})$ or in $\alpha \mathrm{MEM}+$ $10 \%$ PL + antibiotic $(\mathbf{b}, \mathbf{d})$. To note the absence of difference in morphology. Magnification 40x.
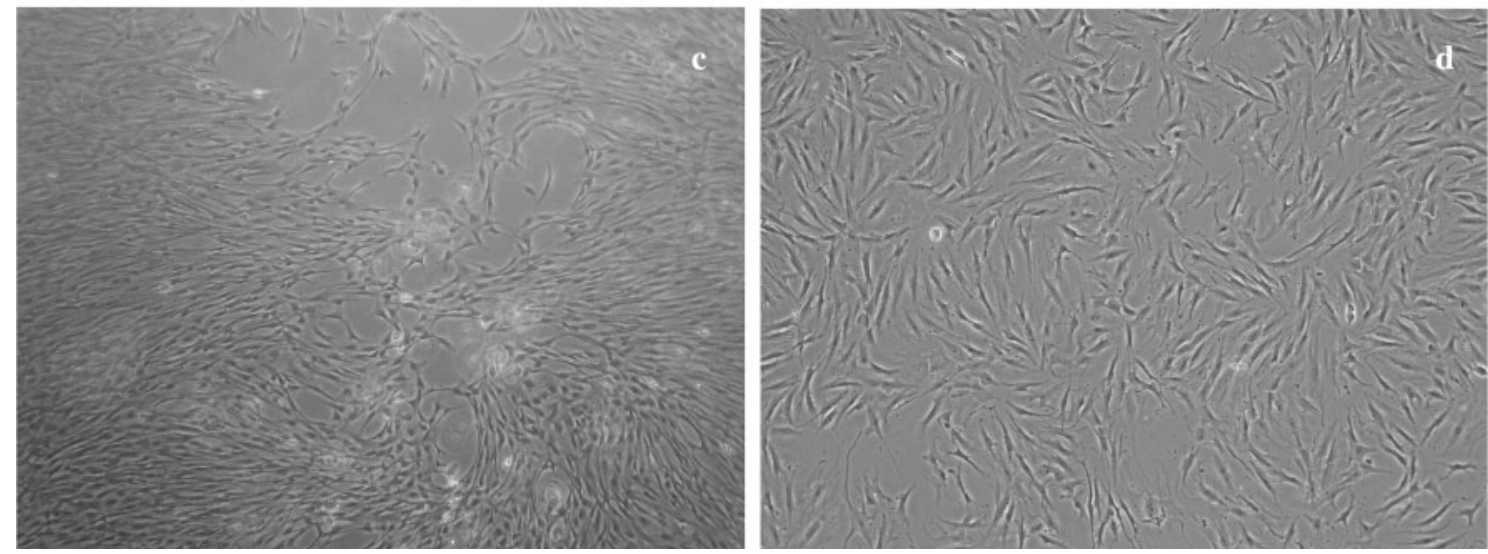

ty progressively lost with increasing cell passages [56]. These deteriorations are more marked with the age of the donor [8]. The aging of MSCs during the expansion could be related to telomere length [8].

\section{Culture Medium and Growth Factors}

The culture medium is a crucial element for obtaining MSCs. The basic medium used can have many formulations. The most-used media are $\alpha$-modified Eagle's medium ( $\alpha \mathrm{MEM})$ and Dulbecco's MEM (DMEM) with low content of glucose. However, other formulations are the McCoy medium, RMPI 1640 or Iscove MEM (IMDM).

From the beginning of MSC culture experiments, Caplan and colleagues [57] highlighted that the basic medium is not sufficient to ensure adhesion and the proliferation of MSCs. One or more supplements should be added. Initially, MSCs were cultivated with fetal calf serum (FCS). The batch of FCS must be evaluated carefully to allow for optimal growth of MSCs and can vary in composition and quality from lot to lot. MSCs may be decreased in number to a maximum of 5 times, and the multipotentiality could be reduced with certain batches of FCS [58]. The concentrations used vary from 10 to $20 \%$. FCS provides the growth factors necessary for cell proliferation and the proteins for attachment. FCS can be replaced by human serum or an equivalent. Results of the use of human serum are somewhat contradictory: the effects are worse than or equivalent to that with FCS $[59,60]$. The differences may be due to the autologous or allogeneic nature of the preparation $[60,61]$. We have also found variable results with preparations from different suppliers. The addition of fibroblast growth factor 2 (FGF-2) to the human serum could mitigate this variability [62]. Another solution is to use the growth factors contained in platelets (platelet-derived growth factor (PDGF), EGF, VEGF, etc.), which are strongly mitogenic for MSCs and have been used since the 1980s [63-66]. The preparation can be obtained by activation of platelets, for example with thrombin, or simply by a cycle of freezing/thawing that destroys the platelets and releases growth factors [64, 67]. In our experience, this substitute for FCS is effective for MSCs and for ASCs. In general, the cells grow more quickly with this process but retain their general morphology (fig. 2).

However, the sera also contain indefinite factors that can influence the physiology of the MSCs or modify the gene expression. Thus, the ability to cultivate MSCs in a definite medium is of interest. In the 1990s, at least two teams described formulations allowing the growth of MSCs in such a medium [57, 68]. Unfortunately, the formulations do not contain molecules ensuring MSC adhesion, which necessitates adsorbing a protein of attachment (fibronectin) on the surface of the culture. Moreover, they do not contain growth factors which must be added to the medium. No major developments in formulations have been published since then.

As we noted previously, a certain number of cytokines active in MSCs include PDGF, EGF, transforming growth factor $\beta$ 
(TGF- $\beta$ ), insulin-like growth factor 1 (IGF-1) and FGF-2 [57, 68]. Among them, FGF-2 appears to be the major cytokine for MSCs. It stimulates the proliferation of all cells of mesodermal origin. In culture, MSCs express the receptors for FGF-1 and FGF-2, and under all conditions of culture, FGF-2 increases the proliferation of MSCs, with growth into multiple layers. This effect begins at low concentrations $(0.2 \mathrm{ng} / \mathrm{ml})$ and reaches a plateau at $20 \mathrm{ng} / \mathrm{ml}$. FGF-2 does not seem to increase the CFU-F frequency but has promoter activity for proliferation rate. FGF-2 maintains the multipotentiality and could increase the frequency of tri-potential progenitors $[56,69]$. Thus, during culture, it could select the more immature progenitors [69]. Surprisingly, FGF-2 seems not to be active when MSCs are cultured in serum-free medium [68]. FGF-2 is currently being used in a clinical trial to complement FCS for the amplification of MSCs.

The other most potent growth factor is EGF, which enhances MSC proliferation both in serum-containing and serum-free medium and synergizes with both PDGF and FGF-2 [68, 70]. However, EGF seems not able to maintain the differentiation potential of MSCs as well as FGF-2. EGF also increases the migration of MSCs [71]. PDGF is a proliferation factor in serum-free medium, but not in FCS-containing medium, possibly because serum contains a large quantity of this factor. In human plasma enriched with platelet growth factors, PDGF $\mathrm{AA}, \mathrm{AB}$ and $\mathrm{BB}$ are the major cytokines and seem to play a pivotal role in the proliferation of the mesenchymal progenitor cells $[64,65]$.

A discussion of the particular conditions of culture that allow for increasing the potential of MSCs is necessary. In 2001, Verfaillie and colleagues [72] described the multipotent adult progenitor cell (MAPC). The culture conditions were based on the medium described by Caplan and associates [57] and cell density based on the work of Prockop and coworkers (culture at low density) [55]. This culture technique allows for optimal proliferation of cells and maintenance or acquisition of a differentiation potential covering the 3 embryonic layers [72-74]. Another team added hypoxia $\left(3 \% \mathrm{O}_{2}\right)$ to a similar culture technique [75]. This team also obtained cells that have a very strong capacity for proliferation but express very immature cell markers (Oct-4, rex-1 and htert) and have ectodermal and endodermal differentiation potential. Lastly, Prockop and coworkers [76] showed that prolonged serum deprivation allowed for selecting a population of very undifferentiated cells that express several embryonic markers. However, all these techniques have been difficult to reproduce in other laboratories.

In conclusion, mesenchymal cells exist in almost all tissues, with similar phenotype and very similar potential of differentiation. The techniques that allow for their isolation and cultivation are also very similar. Thanks to their properties, these cells are very promising tools for regenerative medicine.

\section{References}

1 Owen M, Friedenstein AJ: Stromal stem cells: marrow-derived osteogenic precursors. Ciba Found Symp 1988;136:42-60.

2 Phinney DG, Kopen G, Isaacson RL, Prockop DJ: Plastic adherent stromal cells from the bone marrow of commonly used strains of inbred mice: variations in yield, growth, and differentiation. $\mathrm{J}$ Cell Biochem 1999;72:570-585.

3 Schrepfer S, Deuse T, Lange C, Katzenberg R, Reichenspurner H, Robbins RC, Pelletier MP: Simplified protocol to isolate, purify, and culture expand mesenchymal stem cells. Stem Cells Dev 2007;16: 105-157.

4 Castro-Malaspina H, Gay RE, Resnick G, Kapoor N, Meyers P, Chiarieri D, McKenzie S, Broxmeyer HE, Moore MA: Characterization of human bone marrow fibroblast colony-forming cells (CFU-F) and their progeny. Blood 1980;56:289-301.

5 Caplan AI: Mesenchymal stem cells. J Orthop Res 1991;9:641-650.

6 Horwitz EM, Le Blanc K, Dominici M, Mueller I, Slaper-Cortenbach I, Marini FC, Deans RJ, Krause DS, Keating A: Clarification of the nomenclature for MSC: The International Society for Cellular Therapy position statement. Cytotherapy 2005;7: 393-395.

7 Loeffler M, Potten CS: Stem cells and cellular pedigrees - a conceptual introduction; in Potten CS (ed): Stem Cells. New York, Academic Press, 1997, pp 119-146.
8 Baxter MA, Wynn RF, Jowitt SN, Wraith JE, Fairbairn LJ, Bellantuono I: Study of telomere length reveals rapid aging of human marrow stromal cells following in vitro expansion. Stem Cells 2004;22: 675-682.

$\checkmark 9$ Muschler GF, Boehm C, Easley K: Aspiration to obtain osteoblast progenitor cells from human bone marrow: the influence of aspiration volume. J Bone Joint Surg Am 1997;79:1699-1709.

10 McLain RF, Fleming JE, Boehm CA, Muschler GF: Aspiration of osteoprogenitor cells for augmenting spinal fusion: comparison of progenitor cell concentrations from the vertebral body and iliac crest. J Bone Joint Surg Am 2005;87:2655-2661.

11 Hernigou P, Beaujean F, Lambotte JC: Decrease in the mesenchymal stem-cell pool in the proximal femur in corticosteroid-induced osteonecrosis. J Bone Joint Surg Br 1999;81:349-355.

12 Lee HS, Huang GT, Chiang H, Chiou LL, Chen $\mathrm{MH}$, Hsieh $\mathrm{CH}$, Jiang CC: Multipotential mesenchymal stem cells from femoral bone marrow near the site of osteonecrosis. Stem Cells 2003;21: 190-199.

13 Tuli R, Tuli S, Nandi S, Wang ML, Alexander PG, Haleem-Smith H, Hozack WJ, Manner PA, Danielson KG, Tuan RS: Characterization of multipotential mesenchymal progenitor cells derived from human trabecular bone. Stem Cells 2003;21: 681-693.

14 da Silva Meirelles L, Chagastelles PC, Nardi NB: Mesenchymal stem cells reside in virtually all postnatal organs and tissues. J Cell Sci 2006;119: 2204-2213.
15 Young HE, Steele TA, Bray RA, Hudson J, Floyd JA, Hawkins K, Thomas K, Austin T, Edwards C, Cuzzourt J, Duenzil M, Lucas PA, Black AC: Human reserve pluripotent mesenchymal stem cells are present in connective tissues of skeletal muscle and dermis derived from fetal, adult, geriatric donors. Anat Rec 2001;264:51-62.

16 Lee RH, Kim B, Choi I, Kim H, Choi HS, Suh K, Bae YC, Jung JS: Characterization and expression analysis of mesenchymal stem cells from human bone marrow and adipose tissue. Cell Physiol Biochem 2004;14:311-324

17 Zuk PA, Zhu M, Mizuno H, Huang J, Futrell JW, Katz AJ, Benhaim P, Lorenz HP, Hedrick MH: Multilineage cells from human adipose tissue: implications for cell-based therapies. Tissue Eng 2001;7: 211-228.

18 Zuk PA, Zhu M, Ashjian P, De Ugarte DA, Huang JI, Mizuno H, Alfonso ZC, Fraser JK, Benhaim P, Hedrik MH: Human adipose tissue is a source of multipotent stem cells. Mol Biol Cell 2002;13: 4279-4295.

19 Puissant B, Barreau C, Bourin P, Clavel C, Corre J, Bousquet C, Taureau C, Cousin B, Abbal M, Laharrague $\mathrm{P}$, Penicaud L, Casteilla L, Blancher A: Immunomodulatory effect of human adipose tissuederived adult stem cells: comparison with bone marrow mesenchymal stem cells. Br J Haematol 2005;129:118-129.

20 Varma MJ, Breuls RG, Schouten TE, Jurgens WJ, Bontkes HJ, Schuurhuis GJ, van Ham SM, van Milligen FJ: Phenotypical and functional characterization of freshly isolated adipose tissue-derived stem cells. Stem Cells Dev 2007;16:91-104. 
21 Planat-Benard V, Silvestre JS, Cousin B, Andre M, Nibbelink M, Tamarat R, Clergue M, Manneville C, Saillan-Barreau C, Duriez M, Tedgui A, Levy B, Penicaud L, Casteilla L: Plasticity of human adipose lineage cells toward endothelial cells: physiological and therapeutic perspectives. Circulation 2004;109:656-663.

22 Planat-Bénard V, Menard C, Andre M, Puceat M, Perez A, Garcia-Verdugo JM, Penicaud L, Casteilla L: Spontaneous cardiomyocyte differentiation from adipose tissue stroma cells. Circ Res 2004;94: 223-229.

23 Mitchell JB, McIntosh K, Zvonic S, Garrett S, Floyd ZE, Kloster A, Di Halvorsen Y, Storms RW, Goh B, Kilroy G, Wu X, Gimble JM: Immunophenotype of human adipose-derived cells: temporal changes in stromal-associated and stem cell-associated markers. Stem Cells 2006;24:376-385.

24 Ye ZQ, Burkholder JK, Qiu P, Schultz JC, Shahidi NT, Yang NS: Establishment of an adherent cell feeder layer from human umbilical cord blood for support of long-term hematopoietic progenitor cell growth. Proc Natl Acad Sci U S A 1994;91:1214012144.

25 Erices A, Conget P, Minguell JJ: Mesenchymal progenitor cells in human umbilical cord blood. $\mathrm{Br}$ J Haematol 2000;109:235-242.

26 Wexler SA, Donaldson C, Denning-Kendall P, Rice C, Bradley B, Hows JM: Adult bone marrow is a rich source of human mesenchymal 'stem' cells but umbilical cord and mobilized adult blood are not. Br J Haematol 2003;121:368-374.

27 Lee OK, Kuo TK, Chen WM, Lee KD, Hsieh SL, Chen TH: Isolation of multipotent mesenchyma stem cells from umbilical cord blood. Blood 2004; 103:1669-1675.

28 Bieback K, Kern S, Kluter H, Eichler H: Critical parameters for the isolation of mesenchymal stem cells from umbilical cord blood. Stem Cells 2004;22: 625-634.

29 Kogler G, Sensken S, Wernet P: Comparative generation and characterization of pluripotent unrestricted somatic stem cells with mesenchymal stem cells from human cord blood. Exp Hematol 2006;34:1589-1595.

-30 Kogler G, Sensken S, Airey JA, Trapp T, Muschen M, Feldhahn N, Liedtke S, Sorg RV, Fischer J, Rosenbaum C, Greschat S, Knipper A, Bender J, Degistirici O, Gao J, Caplan AI, Colletti EJ, Almeida-Porada G, Muller HW, Zanjani E, Wernet P: A new human somatic stem cell from placental cord blood with intrinsic pluripotent differentiation potential. J Exp Med 2004;200:123-135.

31 Fauza D: Amniotic fluid and placental stem cells. Best Pract Res Clin Obstet Gynaecol 2004;18 877-891.

32 Alviano F, Fossati V, Marchionni C, Arpinati M, Bonsi L, Franchina M, Lanzoni G, Cantoni S, Cavallini C, Bianchi F, Tazzari PL, Pasquinelli G, Foroni L, Ventura C, Grossi A, Bagnara GP: Term amniotic membrane is a high throughput source for multipotent mesenchymal stem cells with the ability to differentiate into endothelial cells in vitro. BMC Dev Biol 2007;7:11.

\$3 Miao Z, Jin J, Chen L, Zhu J, Huang W, Zhao J, Qian H, Zhang X: Isolation of mesenchymal stem cells from human placenta: comparison with human bone marrow mesenchymal stem cells. Cell Biol Int 2006;30:681-687.

-34 He Q, Wan C, Li G: Multipotent mesenchymal stromal cells in blood. Stem Cells 2007;25:69-77.

35 Roufosse CA, Direkze NC, Otto WR, Wright NA: Circulating mesenchymal stem cells. Int J Biochem Cell Biol 2004;36:585-597.
6 Kuznetsov SA, Mankani MH, Leet AI, Ziran N, Gronthos S, Robey PG: Circulating connective tissue precursors: extreme rarity in humans and chondrogenic potential in guinea pigs. Stem Cells 2007;25:1830-1839.

37 Rochefort GY, Delorme B, Lopez A, Hérault O, Bonnet P, Charbord P, Eder V, Domenech J: Multipotential mesenchymal stem cells are mobilized into peripheral blood by hypoxia. Stem Cells 2006; 24:2202-2208.

38 Eghbali-Fatourechi GZ, Lamsam J, Fraser D, Nagel D, Riggs BL, Khosla S: Circulating osteoblastlineage cells in humans. N Engl J Med 2005;352: 1959-1966.

39 Shi S, Robey PG, Gronthos S: Comparison of human dental pulp and bone marrow stromal stem cells by cDNA microarray analysis. Bone 2001;29: 532-539.

40 Seo BM, Miura M, Gronthos S, Bartold PM, Batouli S, Brahim J, Young M, Robey PG, Wang CY, Shi S: Investigation of multipotent postnatal stem cells from human periodontal ligament. Lancet 2004;364:149-155.

41 Sakaguchi Y, Sekiya I, Yagishita K, Muneta T: Comparison of human stem cells derived from various mesenchymal tissues: superiority of synovium as a cell source. Arthritis Rheum 2005;52:2521-2529.

42 Asakura A, Komaki M, Rudnicki MA: Muscle satellilte cells are multipotential stem cells that exhibit myogenic, osteogenic, and adipogenic differentiation. Differentiation 2001;68:245-253.

43 Kolf CM, Cho E, Tuan RS: Mesenchymal stromal cells. Biology of adult mesenchymal stem cells: regulation of niche, self-renewal and differentiation. Arthritis Res Ther 2007;9:204.

44 Majumdar MK, Thiede MA, Mosca JD, Moorman M, Gerson SL: Phenotypic and functional comparison of cultures of marrow-derived mesenchymal stem cells (MSCs) and stromal cells. J Cell Physiol 1998;176:57-66.

45 Colter DC, Class R, DiGirolamo C, Prockop DJ: Rapid expansion of recycling stem cells in cultures of plastic-adherent cells from human bone marrow. Proc Natl Acad Sci U S A 2000;97:3213-3218.

46 Prockop DJ, Sekiya I, Colter DC: Isolation and characterization of rapidly self-renewing stem cells from cultures of human marrow stromal cells. Cytotherapy 2001;3:393-396.

47 Colter DC, Sekiya I, Prockop DJ: Identification of a subpopulation of rapidly self-renewing and multipotential adult stem cells in colonies of human marrow stromal cell. Proc Natl Acad Sci U S A 2001;98: 7841-7845.

48 Fehrer C, Brunauer R, Laschober G, Unterluggauer H, Reitinger S, Kloss F, Gully C, Gassner R, Lepperdinger G: Reduced oxygen tension attenuates differentiation capacity of human mesenchymal stem cells and prolongs their lifespan. Aging Cell 2007;6:745-757.

49 Grayson WL, Zhao F, Bunnell B, Ma T: Hypoxia enhances proliferation and tissue formation of human mesenchymal stem cells. Biochem Biophys Res Commun 2007;358:948-953.

50 Ohnishi S, Yasuda T, Kitamura S, Nagaya N: Effect of hypoxia on gene expression of bone marrow-derived mesenchymal stem cells and mononuclear cells. Stem Cells 2007;25:1166-1177.

51 Hung SC, Pochampally RR, Hsu SC, Sanchez C, Chen SC, Spees J, Prockop DJ: Short-term exposure of multipotent stromal cells to low oxygen increases their expression of CX3CR1 and CXCR4 and their engraftment in vivo. PLoS ONE 2007;2: e416.
52 Pittenger MF, Mackay AM, Beck SC, Jaiswal RK, Douglas R, Mosca JD, Moorman MA, Simonetti DW, Craig S, Marshak DR: Multilineage potential of adult human mesenchymal stem cells. Science 1999;284:143-147.

53 Bourin P, Gadelorge M: The hopes of the mesenchymal stem cells in regenerative medicine. Transfus Clin Biol 2007;14:120-126.

54 DiGirolamo CM, Stokes D, Colter D, Phinney DG, Class R, Prockop DJ: Propagation and senescence of human marrow stromal cells in culture: a simple colony-forming assay identifies samples with the greatest potential to propagate and differentiate. $\mathrm{Br}$ J Haematol 1999;107:275-281.

55 Sekiya I, Larson BL, Smith JR, Pochampally RR, Cui JG, Prockop DJ: Expansion of human adult stem cells from bone marrow stroma: conditions that maximize the yields of early progenitors and evaluate their quality. Stem Cells 2002;20:530-541.

56 Muraglia A, Cancedda R, Quarto R: Clonal mesenchymal progenitors from human bone marrow differentiate on vitro according to a hierarchical model. J Cell Sci 2000;113:1161-1166.

57 Lennon DP, Haynesworth SE, Young RG, Dennis JE, Caplan AI: A chemically defined medium supports in vitro proliferation and maintains the osteochondral potential of rat marrow-derived mesenchymal stem cells. Exp Cell Res 1995;219: 211-222.

58 Lennon DP, Haynesworth SE, Bruder SP, Jaiswal N, Caplan AI: Human and animal mesenchymal progenitor cells from bone marrow: identification of serum for optimal selection and proliferation. In Vitro Cell Dev Biol 1996;32:602-611.

59 Kuznetsov SA, Mankani MH, Gehron Robey P: Effect of serum on human bone marrow stromal cells: ex vivo expansion and in vivo bone formation. Transplantation 2000;70:1780-1787.

60 Stute N, Holtz K, Bubenheim M, Lange C, Blake F, Zander AR: Autologous serum for isolation and expansion of human mesenchymal stem cells for clinical use. Exp Hematol 2004;32:1212-1225.

61 Shahdadfar A, Fronsdal K, Haug T, Reinholt FP, Brinchmann JE: In vitro expansion of human mesenchymal stem cells: choice of serum is a determinant of cell proliferation, differentiation, gene expression, andtranscriptome stability. Stem Cells 2005;23:1357-1366.

62 Yamaguchi M, Hirayama F, Wakamoto S, Fujihara M, Murahashi H, Sato N, Ikebuchi K, Sawada K, Koike T, Kuwabara M, Azuma H, Ikeda H: Bone marrow stromal cells prepared using $\mathrm{AB}$ serum and bFGF for hematopoietic stem cells expansion. Transfusion 2002;42:921-927.

63 Schwartz KA, Lu G, Trosko JE, Chang CC: Serum from outdated human platelet concentrates: an alternative supplement for tissue (fibroblast) culture media. Am J Hematol 1984;17:23-27.

64 Lucarelli E, Beccheroni A, Donati D, Sangiorgi L, Cenacchi A, Del Vento AM, Meotti C, Bertoja AZ Giardino R, Fornasari PM, Mercuri M, Picci P: Platelet-derived growth factors enhance proliferation of human stromal stem cells. Biomaterials 2003;24:3095-3100.

65 Kilian O, Flesch I, Wenisch S, Taborski B, Jork A, Schnettler R, Jonuleit T: Effects of platelet growth factors on human mesenchymal stem cells and human endothelial cells in vitro. Eur J Med Res 2004;9:337-344.

66 Kocaoemer A, Kern S, Klüter H, Bieback K: Human AB serum and thrombin-activated plateletrich plasma are suitable alternatives to fetal calf serum for the expansion of mesenchymal stem cells from adipose tissue. Stem Cells 2007;25:1270-1278. 
67 Schallmoser K, Bartmann C, Rohde E, Reinisch A Kashofer K, Stadelmeyer E, Drexler C, Lanzer G, Linkesch W, Strunk D: Human platelet lysate can replace fetal bovine serum for clinical-scale expansion of functional mesenchymal stromal cells Transfusion 2007;47:1436-1446.

68 Gronthos S, Simmons PJ: The growth factor requirements of STRO-1-positive human bone marrow stromal precursors under serum-deprived conditions in vitro. Blood 1995;85:929-940.

69 Bianchi G, Banfi A, Mastrogiacomo M, Notaro R, Luzzatto L, Cancedda R, Quarto R: Ex vivo enrichment of mesenchymal cell progenitors by fibroblast growth factor 2. Exp Cell Res 2003;287:98-105.

70 Martin I, Muraglia A, Campanile G, Cancedda R, Quarto R: Fibroblast growth factor-2 supports ex vivo expansion and maintenance of osteogenic precursors from human bone marrow. Endocrinology 1997;138:4456-4462.
71 Tamama K, Fan VH, Griffith LG, Blair HC, Wells A: Epidermal growth factor as a candidate for ex vivo expansion of bone marrow-derived mesenchymal stem cells. Stem Cells 2006;24:686-695.

72 Reyes M, Lund T, Lenvik T, Aguiar D, Koodie L, Verfaillie CM: Purification and ex vivo expansion of postnatal human marrow mesodermal progenitor cells. Blood 2001;98:2615-2625.

73 Reyes M, Dudek A, Jahagirdar B, Koodie L, Marker PH, Verfaillie CM: Origin of endothelial progenitors in human postnatal bone marrow. J Clin Invest 2002;109:337-346.

74 Schwartz RE, Reyes M, Koodie L, Jiang Y, Blackstad M, Lund T, Lenvik T, Johnson S, Hu WS, Verfaillie CM: Multipotent adult progenitor cells from bone marrow differentiate into functional hepatocyte-like cells. J Clin Invest 2002;109:1291-1302.
75 D'Ippolito G, Diabira S, Howard GA, Menei P, Roos BA, Schiller PC: Marrow-isolated adult multilineage inducible (MIAMI) cells, a unique population of postnatal young and old human cells with extensive expansion and differentiation potential. $\mathrm{J}$ Cell Sci 2004;117:2971-2981.

76 Pochampally RR, Smith JR, Ylostalo J, Prockop DJ: Serum deprivation of human marrow stromal cells (hMSCs) selects for a subpopulation of early progenitor cells with enhanced expression of OCT-4 and other embryonic genes. Blood 2004;103: 1647-1652.

77 Gimble JM, Guilak F, Nutall ME, Sathishkumar S Vidal M, Bunnell BA: In vitro differentiation of mesenchymal stem cells. Transfus Med Hemother 2008;35(3):228-238.

78 Rojewski MT, Weber BM, Schrezenmeier H: Phenotypic characterization of mesenchymal stem cells from various tissues. Transfus Med Hemother 2008; 35(3):248-259. 